\title{
ANALISIS KELAYAKAN FINANSIAL USAHA PENGGEMUKAN SAPI SIMMENTAL PERANAKAN ONGOLE DAN FAKTOR-FAKTOR YANG BERPENGARUH TERHADAP JUMLAH KEPEMILIKAN PADA PETERNAKAN RAKYAT DI KABUPATEN KARANGANYAR
}

\section{FEASIBILITY ANALYSIS OF SIMMENTAL ONGOLE CROSSBRED CATTLE AND FACTORS INFLUENCING ON CATTLE OWNERSHIP OF SMALL SCALE FARM IN KARANGANYAR DISTRICT}

\author{
Josua Sahala*, Rini Widiati, dan Endang Baliarti \\ Fakultas Peternakan, Universitas Gadjah Mada, Yogyakarta, 55281
}

Submitted: 24 December 2014, Accepted: 2 September 2015

INTISARI

\begin{abstract}
Penelitian ini bertujuan untuk mengetahui kelayakan finansial usaha penggemukan sapi potong di Kabupaten Karanganyar dan faktor-faktor yang mempengaruhi jumlah kepemilikan. Penentuan lokasi berdasarkan metode location quotient (LQ) ditetapkan Kecamatan Jenawi, Jatiyoso dan Mojogedang. Pengambilan sampel responden ditentukan secara purposive sampling sebanyak 40 peternak penggemukan sapi Simmental-Peranakan Ongole (SimPO). Metode pengambilan data adalah survei untuk mengumpulkan data primer dari responden dan data sekunder dari dinas terkait. Analisis kelayakan finansial menggunakan kriteria net present value (NPV), benefit cost ratio (BCR), internal rate of return (IRR), payback period of credit (PPC), dilanjutkan dengan break event point (BEP). Untuk mengetahui faktor-faktor yang berpengaruh terhadap jumlah kepemilikan sapi digunakan analisis regresi linear berganda. Hasil analisis menunjukkan bahwa secara finansial usaha penggemukan sapi SimPO dengan jangka waktu 5 tahun dan discount factor 12\%/tahun layak diusahakan. Hasil analisis regresi menunjukkan bahwa luas lahan pertanian berpengaruh positif dan nyata $(P<0,01)$ dan pengalaman usaha serta jumlah ketersediaan tenaga kerja juga berpengaruh positif $(P<0,1)$ terhadap jumlah kepemilikan sapi potong. Dari penelitian disimpulkan bahwa usaha penggemukan sapi SimPO di Kabupaten Karanganyar berpotensi untuk dikembangkan.
\end{abstract}

(Kata kunci: Break event point, Kelayakan finansial, Penggemukan sapi SimPO, Peternakan rakyat, Regresi linear berganda)

\begin{abstract}
This study was done to determine the financial feasibility of beef cattle fattening and the factors affecting the number of cattle ownership of small scale farmer in Karanganyar District. The location quotient (LQ) selected were Jenawi, Jatiyoso and Mojogedang sub-districts. Respondents were determined by purposive sampling of 40 SimPO cattle farmers. Survey method was adopted to collect the primary data from respondents and the secondary data from relevant offices. The criteria for feasibility analysis was net present value (NPV), benefit cost ratio (BCR), internal rate of return (IRR), followed by payback period of credit (PPC) and break event point (BEP). Multiple regression linear analysis was used to determine the factors that influence the number of cattle ownership. The results of analysis showed that financially SimPO cattle fattening with a period of 5 years and a discount factor of 12\%/year was feasible. Regression analysis showed that there were positive effects $(P<0.01)$ of agricultural land, beef cattle business experience and the number of labour on the number of beef cattle ownership. It was concluded that SimPO cattle fattening in Karanganyar was feasible.
\end{abstract}

(Key words: Break event point, Fattening, Financial analysis, Multiple regresion linear analysis, Simmental Ongole Crossbred cattle, Small scale farmer)

\footnotetext{
* Korespondensi (corresponding author):

Telp. +6281263037054

E-mail: jose_mid3kill@yahoo.com
} 


\section{Pendahuluan}

Usaha penggemukan sapi potong merupakan usaha yang potensial dalam rangka pemenuhan swasembada daging sapi nasional dan diharapkan dapat mengurangi ketergantungan terhadap impor sapi dan daging sapi. Usaha ini dilakukan oleh peternak skala besar maupun skala rumah tangga namun usaha sapi potong memerlukan biaya investasi yang cukup besar (Atmakusuma et al., 2011).

Di Indonesia lebih dari 90\%, sapi diusahakan oleh peternakan rakyat dengan skala kecil, modal lemah serta masih bersifat usaha sampingan (Yusdja dan Ilham, 2006). Sapi SimPO merupakan sapi hasil persilangan antara pejantan sapi Simmental dengan induk sapi Peranakan Ongole (PO) yaitu kebanyakan merupakan hasil perkawinan dengan inseminasi buatan (IB). Sapi SimPO mempunyai darah dari sapi Simmental dan Peranakan Ongole, sehingga ciri-ciri sapi ini dapat menyerupai sapi Simmental, Peranakan Ongole atau perpaduan ciri-ciri Simmental dan Peranakan Ongole (Ngadiyono, 2007). Sapi SimPO terkenal karena menyusui anaknya dengan baik, pertumbuhannya cepat dan badan panjang dan padat (Ngadiyono, 2012). Kondisi saat ini menunjukkan bahwa para peternak sapi potong penggemukan lebih menyukai memelihara sapi SimPO dikarenakan pertumbuhan berat badan tinggi, asal pakan dan pemeliharaan yang diberikan mencukupi kebutuhannya.

Kabupaten Karanganyar merupakan salah satu kabupaten yang memiliki potensi dalam bidang peternakan. Populasi sapi potong Kabupaten Karanganyar selalu mengalami kenaikan, sebagai gambaran pada tahun 2008 populasi sebesar 47.468 ekor, meningkat menjadi 80.078 ekor tahun 2012 atau mengalami rerata kenaikan dalam lima tahun terakhir sebesar $15,28 \%$ per tahun (BPS Kabupaten Karanganyar, 2013) dan lebih tinggi di atas rerata nasional sebesar $6,87 \%$ dan Jawa Tengah sebesar $9,55 \%$. Sebagian besar sapi yang dipelihara masih diusahakan oleh peternakan rakyat sebagai usaha sambilan dengan jumlah kepemilikan 2-3 ekor. Meskipun demikian usaha sapi potong membutuhkan investasi yang besar, oleh karena itu perlu dilakukan kelayakan investasi usaha. Kelayakan usaha penggemukan dapat di-lakukan melalui analisis dengan meng-gunakan metode net present value (NPV), internal rate of return (IRR), benefit cost ratio (BCR), dan payback period (PP) (Gittinger, 1986; Pudjosumarto, 1991; Gray dan Simanjuntak, 1993; Husnan dan Sarwono, 1994; Kadariah et al., 1999; Haming dan Basalamah, 2003; Ibrahim, 2003; Soekartawi, 2006; Kasmir dan Jakfar, 2007; Jumingan, 2009; Umar, 2009). Di samping itu peneliti juga ingin mengetahui faktor-faktor yang berpengaruh terhadap jumlah kepemilikan ternak yang diharapkan sebagai insentif untuk meningkatkan usaha. Secara teoritis banyak faktor yang berpengaruh antara lain umur responden, luas lahan pertanian, tingkat pendidikan, pengalaman usaha, dan jumlah ketersediaan. Penelitian ini dilakukan dengan tujuan mengetahui kelayakan finansial usaha penggemukan sapi potong SimPO dan faktor-faktor yang berpengaruh terhadap jumlah kepemilikan peternakan rakyat di Kabupaten Karanganyar.

\section{Materi dan Metode}

Penelitian dilaksanakan pada bulan Oktober sampai bulan Desember 2013 di tiga kecamatan yaitu Kecamatan Jenawi, Jatiyoso dan Mojogedang Kabupaten Karanganyar Propinsi Jawa Tengah. Pemilihan kecamatan sebagai lokasi penelitian dilakukan secara purposive berdasarkan nilai tertinggi dengan menggunakan metode location quotient (LQ) (Budiharsono, 2001; Tarigan, 2007). Masingmasing kecamatan diambil dua desa yang memiliki populasi sapi potong terbanyak. Sampel diambil sebanyak 40 responden penggemukan sapi SimPO secara purposive quota sampling berdasarkan kepemilikan paling sedikit 2 ekor sapi dan pengalaman beternak lebih dari 2 tahun. Metode yang digunakan dalam penelitian ini adalah metode survei dengan menggunakan bantuan kuesioner.

Data yang diambil meliputi karakteristik responden yaitu usia, pendidikan formal, pekerjaan utama, jumlah anggota keluarga produktif, pengalaman beternak, dan luas kepemilikan lahan (ha) serta parameter teknis dan ekonomi yang berpengaruh terhadap penerimaan dan biaya. Metode analisis kelayakan usaha menggunakan kriteria NPV, BCR, IRR dan PPC dilanjutkan dengan BEP. Analisis faktorfaktor yang berpengaruh terhadap ke- 
pemilikan ternak menggunakan regresi berganda (Gujarati, 2003).

\section{Hasil dan Pembahasan}

\section{Karakteristik peternak}

Rerata usia respoden adalah $50,5 \pm 10,8$ tahun yang berarti termasuk dalam usia produktif. Usia termasuk faktor yang berpengaruh terhadap kerja dan pola pikir peternak responden terutama dalam menentukan corak dan pola manajemen yang akan dilakukan (Djaelani et al., 2009). Pendapat ini dipertegas oleh Setiadi et al. (2012) bahwa pada usia produktif peternak akan lebih mudah mengembangkan usaha peternakan yang telah dijalankan.

Dari segi tingkat pendidikan formal yang dicapai peternak bervariasi mulai dari pendidikan SD, SMP, SMA dan PT, yang paling banyak pada tingkat SD sebesar $55 \%$ dan paling sedikit di PT hanya $5 \%$ sehingga dapat dikatakan bahwa tingkat pendidikan responden masih rendah. Tingkat pendidikan berperan dalam mendukung pengetahuan zooteknik, sehingga semakin tinggi tingkat pendidikan akan semakin mudah menerima dan menyerap inovasi baru serta menerapkan teknologi yang sesuai dengan kondisi di lapangan untuk meningkatkan produktivitas dan pendapatan (Roessali et al., 2005; Emawati et al., 2008).

Sebagian besar pekerjaan utama peternak adalah petani dengan lahan sendiri sebanyak 67,5\%. Komoditi yang ditanam yaitu padi, ubi kayu, cabai dan kedelai yang mendukung usaha sapi potong. Pekerjaan selain petani yaitu swasta (15\%), buruh tani $(7,5 \%)$, pedagang dan PNS masing-masing $5 \%$. Data ini menunjukkan bahwa usaha sapi potong diminati berbagai macam lapisan pekerjaan karena ternak sapi potong dianggap masih dapat memberikan tambahan penghasilan di sela waktu kosong. Responden memelihara sapi potong sebagai tabungan sekaligus menambah penghasilan keluarga. Elly et al., 2008 dan Hartatik et al., 2009 menyatakan bahwa usaha pemeliharaan sapi masih dilakukan secara tradisional dengan menggunakan teknologi sederhana sebagai usaha sampingan karena mata pencaharian peternak sebagian besar merupakan petani.

Jumlah anggota keluarga yang produktif berkisar 4-6 orang, sebanyak 20 responden atau $50 \%$ dari jumlah keseluruhan. Besar kecilnya jumlah anggota keluarga produktif dalam usaha sapi potong sangat berpengaruh terhadap produktivitas kerja dan kemampuan dalam mengelola usaha yang dijalankan. Tenaga kerja yang digunakan berasal dari keluarga sendiri (istri, adik, anak, mertua) dan luar keluarga seperti tetangga yang masih punya hubungan saudara. Sitindaon dan Zurriyati (2012) berpendapat bahwa umumnya pekerjaan bidang peternakan dilakukan oleh kaum laki-laki karena pekerjaan bidang peternakan membutuhkan tenaga yang besar dan kuat sedangkan kaum perempuan bersifat membantu.

Rerata pengalaman beternak adalah $19,35 \pm 10,78$ tahun. Hal ini menunjukkan bahwa responden penggemukan sapi potong mayoritas sudah berpengalaman dalam beternak sapi potong lebih dari 10 tahun. Pengalaman beternak sangat berhubungan erat dengan pengambilan keputusan dalam proses produksi. Luanmase et al. (2011) menjelaskan apabila peternak memiliki pengalaman beternak tinggi akan semakin meningkatkan motivasi kerja, yang pada akhirnya memperlihatkan keberhasilan dalam kegiatan usaha peternakan. Hal yang sama juga dikemukakan oleh Sitindaon dan Zurriyati (2012) bahwa pengalaman beternak diperoleh dari orang tuanya secara turun temurun melalui penyuluhan atau pelatihan memberikan indikasi bahwa pengetahuan dan keterampilan beternak serta manajemen pemeliharaan ternak yang dimiliki petani cukup baik.

Luas kepemilikan lahan sebesar $0,54 \pm 0,79$ ha. Hal ini menunjukkan luas kepemilikan lahan cukup tinggi melebihi yang dilaporkan oleh Susilowati et al. (2008) bahwa sebagaian besar rumah tangga petani di Jawa memiliki lahan pertanian kurang dari 0,5 ha dengan kepemilikan lahan terbanyak sebesar 0,25 ha. Tingginya kepemilikan lahan pertanian milik responden dikarenakan daerah lokasi penelitian yang berbukit-bukit dimanfaatkan oleh peternak untuk tanaman pertanian dan memelihara ternak yang saling mendukung.

\section{Parameter teknis dan ekonomi usaha penggemukan sapi}

Parameter teknis. Jenis sapi bakalan yang dipelihara adalah sapi SimPO dengan jangka waktu pemeliharaan sekitar 4 bulan. Pakan hijauan diberikan dua kali dalam 
sehari yaitu pada pagi dan siang hari. Jenis hijauan yang biasa diberikan berupa rumput gajah sebanyak 20,15 kg/ekor/hari dengan harga Rp500,00/kg, tebon jagung sebanyak 2,33 kg/ekor/hari dengan harga Rp450,00/kg, jerami padi sebanyak 8,925 $\mathrm{kg} / \mathrm{ekor} /$ hari dengan harga Rp250,00/kg. Pakan penguat berupa bekatul diberikan pada siang atau sore hari sebanyak 6,9 $\mathrm{kg} / \mathrm{ekor} /$ hari dengan harga Rp2.800,00/kg. Ukuran kandang yang dimiliki untuk usaha penggemukan adalah 26,45 $\mathrm{m}^{2}$ dengan rerata kepemilikan ternak 3 ekor.

Parameter ekonomis. Biaya investasi adalah biaya yang dikeluarkan oleh peternak saat memulai usaha penggemukan sapi potong. Biaya investasi meliputi pembuatan kandang sebesar Rp7.074.125,00 sedangkan biaya peralatan sebesar Rp124.875,00 berupa cangkul, sapu lidi, sekop, garuk, ember, selang, dan sepatu boots. Sapi bakalan yang diperoleh berasal pembeliaan langsung dari pasar hewan. Rerata kepemilikan sapi SimPO di Kabupaten Karanganyar sebanyak 3 ekor dengan biaya membeli bakalan sebesar Rp68.438.425,20. Rerata biaya pakan sebesar Rp8.548.731,495,00. Pakan yang diberikan dalam berupa hijauan rumput gajah dengan harga sebesar Rp500,00/kg, jerami sebesar Rp250,00/kg, ketela pohon sebesar Rp1.750,00/kg, tebon jagung sebesar $\mathrm{Rp} 450,00 / \mathrm{kg}$ dan konsentrat berupa bekatul sebesar Rp2.800,00/kg. Biaya kesehatan yang dikeluarkan oleh peternak tergantung dari pengeluaran akan kebutuhan obat- obatan dan biaya dalam memanggil mantri. Rerata total biaya yang dikeluarkan sebesar Rp74.338,58.

Biaya tenaga kerja bermacam-macam, terdiri dari pemberian hijauan, pemberian konsentrat, pemberian minum, membersihkan kandang, memandikan sapi, dan mencari hijauan. Masing-masing peternak melakukan kegiatan membutuhkan waktu yang berbeda-beda. Tabel 1 menunjukkan rerata biaya pakan yang dikeluarkan dalam usaha sebesar Rp8.548.731,49. Besarnya biaya perbaikan kandang yang dikeluarkan pada usaha penggemukan sapi SimPO di Kabupaten Karanganyar sebesar Rp442.000.

Biaya peralatan adalah biaya pembelian alat yang dikeluarkan dalam satu tahun saat usaha dijalankan. Rerata biaya peralatan sebesar Rp69.000,00. Rerata biaya air dan listrik yang dikeluarkan oleh peternak penggemukan sapi SimPO di lokasi penelitian sebesar Rp116.500,00. Air yang digunakan berasal dari mata air yang disalurkan ke setiap rumah melalui pipa-pipa kecil. Air digunakan untuk memberi minuman dan memandikan sapi sedangkan listrik digunakan untuk penerangan kandang dengan menggunakan lampu.

\section{Kriteria kelayakan finansial usaha sapi SimPO}

Cash flow. Penerimaan usaha penggemukan sapi potong berasal dari penjualan produk sampingan berupa kotoran feses basah dan hasil sisa kandang. Nilai sisa

Tabel 1. Rerata parameter ekonomi usaha penggemukan sapi SimPO di Kabupaten Karanganyar (average of economic parameters of SimPO beef cattle fattening in Karanganyar District)

\begin{tabular}{lr}
\hline \hline \multicolumn{1}{c}{ Parameter ekonomi (economic parameters) } & Biaya (Rp) (cost (IDR)) \\
\hline Investasi (investment) & $7.074 .125,00$ \\
Pembuatan kandang/peternak (preparation of cage/ respondent) & $124.875,00$ \\
Peralatan/peternak (equipment/respondent) & \\
Biaya produksi & $68.438 .425,20$ \\
Biaya pembelian bakalan/ekor/peternak (cost of purchasing feeder cattle) & $8.548 .731,49$ \\
Biaya pakan (cost of feed) & $74.338,58$ \\
Biaya kesehatan/bulan (cost of health/month) & $4.059 .566,93$ \\
Biaya tenaga kerja/HOK (cost of labor) & $69.000,00$ \\
Biaya peralatan/peternak (cost of equipments/respondent) & $442.000,00$ \\
Biaya perbaikan kandang/peternak (cost of repair cage/respondent) & $116.500,00$ \\
Biaya air dan listrik/bulan (cost of water and electricity/month) & \\
Penerimaan (revenues) & $108.053 .681,10$ \\
Penjualan ternak (sale of cattle) & $3.657 .543,31$ \\
Penjualan kotoran (manure selling) & $707.412,50$ \\
Nilai sisa kandang (salvage value of cage) & \\
\hline Keterangan: Pembelian bakalan dan penjualan ternak sebanyak 3 ekor/periode (dalam satu tahun terdapat 3 periode \\
pembelian bakalan dan 3 periode penjualan ternak) (the purchase and sale of cattle going as much as 3 \\
tails/period (there are 3 periods of the purchase and 3 periods of the sale in one year).
\end{tabular}


kandang adalah nilai akhir kandang setelah digunakan selama pemeliharaan selama 5 tahun (Tabel 2).

Pendapatan usaha penggemukan sapi potong merupakan selisih total penerimaan dikurangi biaya total. Estimasi pendapatan usaha penggemukan ternak sapi SimPO dari tahun ke tahun di Kabupaten Karanganyar disajikan pada Tabel 3.

\section{Kelayakan finansial usaha sapi SimPo}

Hasil kelayakan usaha dapat dilihat pada Tabel 4. Hasil analisis kelayakan menunjukkan bahwa usaha penggemukan sapi potong dengan skala kepemilikan tiga ekor per periode dan tiga ekor per tahun diperoleh nilai NPV sebesar Rp31.263.263,65. Hal ini berarti nilai sekarang yang diterima selama 5 tahun pada tingkat suku bunga $12 \%$ adalah positif. Dari nilai NPV tersebut dapat ditarik kesimpulan bahwa usaha ini layak untuk dijalankan.
Nilai BCR dengan skala kepemilikan tiga ekor pada tingkat suku bunga $12 \%$ sebesar 1,95. Nilai tersebut menggambarkan bahwa setiap pengeluaran biaya sebesar Rp1,00 menghasilkan manfaat bersih sebesar 1,95. Dapat dikatakan bahwa 1,95 kali manfaat bersih yang diperoleh dari setiap biaya yang dikeluarkan. Nilai BCR lebih besar dari satu, menunjukkan bahwa usaha penggemukan sapi potong dengan skala kepemilikan tiga ekor dapat dijalankan.

Nilai IRR yang diperoleh pada usaha penggemukan sapi potong dengan kepemilikan tiga ekor sebesar $20,24 \%$ yang mengandung arti bahwa tingkat pengembalian bila menanamkan modal pada usaha tersebut lebih besar dari tingkat suku bunga yang berlaku. Dari nilai IRR diperoleh dapat disimpulkan bahwa usaha layak untuk dijalankan.

Nilai payback period sebesar 1,87 tahun, sementara jangka waktu investasi adalah 5 tahun. Proyek semakin baik apabila

Tabel 2. Proyeksi total penerimaan usaha penggemukan sapi potong (projected total revenue fattening beef cattle)

\begin{tabular}{cccc}
\hline $\begin{array}{c}\text { Tahun ke- } \\
\text { (years) }\end{array}$ & $\begin{array}{c}\text { Penerimaan produk utama (Rp) } \\
\text { (main product revenues } \\
(I D R))\end{array}$ & $\begin{array}{c}\text { Penerimaan produk } \\
\text { sampingan }(\mathrm{Rp}) \text { (by-product } \\
\text { revenues (IDR) }\end{array}$ & $\begin{array}{c}\text { Total penerimaan } \\
(\mathrm{Rp})(\text { total of } \\
\text { revenues (IDR) }\end{array}$ \\
\hline 0 & - & - & - \\
1 & $108.053 .681,10$ & $3.657 .306,00$ & $111.711 .224,00$ \\
2 & $108.053 .681,10$ & $3.657 .306,00$ & $111.711 .224,00$ \\
3 & $108.053 .681,10$ & $3.657 .306,00$ & $111.711 .224,00$ \\
4 & $108.053 .681,10$ & $3.657 .306,00$ & $111.711 .224,00$ \\
5 & $108.053 .681,10$ & $7.194 .605,80$ & $115.248 .286,90$ \\
\hline
\end{tabular}

Tabel 3. Pendapatan usaha ternak penggemukan sapi SimPO di Kabupaten Karanganyar (revenue of SimPO beef cattle fattening in Karanganyar District)

\begin{tabular}{cccc}
\hline $\begin{array}{c}\text { Tahun ke- } \\
\text { (years) }\end{array}$ & $\begin{array}{c}\text { Total penerimaan (Rp) (total of } \\
\text { revenues }(\text { IDR) })\end{array}$ & $\begin{array}{c}\text { Total biaya (Rp) (total } \\
\text { of cost (IDR)) }\end{array}$ & $\begin{array}{c}\text { Total pendapatan (Rp) } \\
\text { (total of income (IDR)) }\end{array}$ \\
\hline 0 & $111.711 .224,00$ & $32.863 .409,45$ & $-32.863 .409,45$ \\
1 & $111.711 .224,00$ & $93.590 .206,30$ & $18.121 .018,05$ \\
2 & $111.711 .224,00$ & $94.740 .744,36$ & $16.970 .480,05$ \\
3 & $111.711 .224,00$ & $94.740 .744,36$ & $16.970 .480,05$ \\
4 & $115.248 .287,00$ & $94.740 .744,36$ & $16.970 .480,05$ \\
5 & $111.711 .224,00$ & $94.740 .744,36$ & $20.507 .542,55$ \\
\hline
\end{tabular}

Tabel 4. Analisis kelayakan finansial investasi usaha penggemukan sapi potong skala kepemilikan 3 ekor di Kabupaten Karanganyar

(investment analysis of beef cattle fattening with scale 3 heads ownership in Karanganyar District)

\begin{tabular}{lc}
\hline \hline \multicolumn{1}{c}{ Uraian (items) } & $\begin{array}{c}\text { Kepemilikan (3 ekor/peternak dan 3 periode/tahun) } \\
\text { (ownership (three cattle/farmer and three periods/year)) }\end{array}$ \\
\hline Net present value (NPV) & Rp31.263.263,65 \\
Benefit cost ratio (BCR) & 1,95 \\
Internal rate of return (IRR) & $20,24 \%$ \\
Payback period of credit (PPC) & 1,87 tahun (year) \\
\hline
\end{tabular}


waktu pengembalian biaya investasi semakin cepat. Selanjutnya besarnya penjualan ternak yaitu sebesar Rp30.582.616,57. Pada nilai ini peternak mengalami untung dan juga tidak mengalami rugi. Nilai BEP berdasarkan unit ternak yaitu sebanyak 2,55 ekor. Peternak akan memperoleh keuntungan apabila peternak memelihara lebih dari 2,55 UT atau setara 2,55 ekor sapi jantan dewasa.

\section{Faktor-faktor yang berpengaruh terhadap jumlah kepemilikan sapi}

Hasil analisis berganda yang berpengaruh terhadap jumlah kepemilikan sapi dapat dilihat pada Tabel 5. Uji F menunjukkan pengujian secara simultan variabel independen yaitu luas lahan pertanian, tingkat pendidikan, pengalaman usaha dan jumlah ketersediaan tenaga kerja memberikan pengaruh nyata terhadap variabel dependen jumlah kepemilikan ternak. Terlihat bahwa pada taraf kepercayaan 0,05 semua faktor independen secara bersama-sama berpengaruh nyata terhadap variabel dependen dengan $R^{2}$ sebesar 0,341. Nilai $R$ Square sebesar 0,341 atau $34,1 \%$ menunjukkan bahwa keseluruhan variable bebas yang dianalisis sebesar $34,1 \%$ dapat menjelaskan variabel dependen yaitu jumlah kepemilikan ternak, sedangkan sisanya 65,9 dijelaskan oleh faktor lain di luar model yang tidak dimasukkan dalam analisis. Uji t menunjukkan pengujian secara parsial masing-masing faktor atau variabel independen terhadap variabel dependen.

Variabel umur peternak (X1) berpengaruh tidak nyata dan negatif terhadap jumlah ternak $(P<0,01)$. Nilai koefisien regresi sebesar $-0,326$ artinya apabila umur bertambah satu tahun maka jumlah ternak akan berkurang sebesar 0,326 satuan. Hal ini juga dapat dijelaskan bahwa ketika umur peternak bertambah maka jumlah ternak akan berkurang karena intensitas dan perhatian peternak mulai menurun untuk memelihara ternak.

Variabel luas lahan (X2) berpengaruh nyata dan positif $(P<0,01)$. Nilai koefisien regresi sebesar 0,440 artinya apabila luas lahan bertambah satu ha maka jumlah ternak akan bertambah sebesar 0,440 ekor. Lahan menjadi faktor penting, karena ketika berusaha ternak sangat membutuhkan lahan sebagai sumber pakan. Peternak dengan lahan luas akan berusaha sebaik mungkin menambah jumlah ternak karena daya dukung lahan cukup tersedia dengan jumlah pakan yang memadai untuk penambahan ternak.

Variabel tingkat pendidikan (X3) berpengaruh tidak nyata dan positif. Hal ini berarti bahwa menjadi seorang peternak tidak membutuhkan tingkatan pendidikan formal yang tinggi karena pendidikan rendah yang dilengkapi pendidikan non formal maka seorang peternak akan menjadi peternak unggul.

Variabel pengalaman beternak (X4) berpengaruh nyata dan positif terhadap jumlah ternak $(P<0,01)$. Nilai koefisien regresi sebesar 0,413 artinya apabila pengalaman beternak bertambah satu tahun maka jumlah ternak akan bertambah sebesar 0,413 ekor namun penambahan pengalaman usaha berpengaruh nyata terhadap jumlah kepemilikan ternak. Saleh et al. (2006) berpendapat bahwa peternak sapi potong tidak melakukan perubahan positif untuk meningkatkan pengusahaan penggemukan yang telah dijalankan. Banyak pengalaman

Tabel 5. Analisis regresi linear berganda (multiple regression linear analysis)

\begin{tabular}{|c|c|c|c|}
\hline Variabel (variables) & $\begin{array}{c}\text { B } \text { (koefisien } \\
\text { regresi) }\end{array}$ & $\mathrm{t}$ hitung & Sign \\
\hline a (constant) & 9.035 & 2.314 & .27 \\
\hline X1 (umur responden) (respondent age) & -.326 & -1.271 & $.212^{\text {ns }}$ \\
\hline X2 (luas lahan pertanian) (extensive agricultural land) & .440 & 2.974 & $.005^{\star \star \star}$ \\
\hline X3 (tingkat pendidikan) (the education levels) & .116 & .783 & $.439^{\text {ns }}$ \\
\hline X4 (pengalaman beternak) (farming experience) & .413 & 1.714 & $.096^{* \star}$ \\
\hline X5 (jumlah ketersediaan tenaga kerja) (labor availability) & .294 & -1.892 & $.067^{\star \star}$ \\
\hline \multicolumn{4}{|l|}{$\mathrm{R}=.584^{\mathrm{a}}$} \\
\hline $\begin{array}{l}\text { R Square }=.341 \\
\text { Adjusted R Square }=.244 \\
\text { Std. Error of the Estimate }=2.70669 \\
\text { Fhituna }=3.513\end{array}$ & & $011^{\mathrm{a}}$ & \\
\hline & & & \\
\hline
\end{tabular}


yang memadai namun selalu masih mengelola usaha tersebut dengan kebiasaan lama yang sama dengan waktu mengawali usahanya sampai sekarang.

Variabel jumlah ketersediaan tenaga kerja keluarga (X5) berpengaruh nyata dan positif $(P<0,05)$ terhadap jumlah kepemilikan ternak. Hal ini disebabkan karena pada peternakan rakyat hanya menggunakan tenaga kerja keluarga. Mukson et al. (2008) mengatakan bahwa tenaga kerja yang digunakan pada usaha peternakan sapi potong umumnya masih menggunakan tenaga kerja keluarga dan banyak digunakan untuk mencari kegiatan mencari pakan yang biasanya dilakukan bersama-sama dengan kegiatan pertanian.

\section{Kesimpulan}

Usaha penggemukan sapi SimPO di Kabupaten Karanganyar dengan menggunakan jangka waktu investasi 5 tahun, discount factor $12 \%$ layak untuk diusahakan sehingga mempunyai potensi untuk dikembangkan dengan memelihara lebih dari 3 ekor. Faktor-faktor yang berpengaruh nyata dan positif terhadap jumlah kepemilikan ternak adalah luas lahan pertanian, pengalaman beternak dan tenaga kerja. Faktor pemilikan lahan pertanian, pengalaman usaha dan jumlah ketersediaan tenaga kerja keluarga merupakan faktor yang perlu diperhatikan untuk memperhitungkan jumlah sapi yang dipelihara pada usaha peternakan rakyat.

\section{Daftar Pustaka}

Atmakusuma, J., T. Sarianti, dan A. Ristianingrum. 2011. Analisis kelayakan usaha pembibitan dan penggemukan sapi potong dalam rangka swasembada daging nasional. HIm 141-157. Prosiding Seminar Penelitian Unggulan Departemen Agribisnis, Bogor 7 dan 14 Desember 2011. Fakultas Ekonomi dan Manajemen, Institut Pertanian Bogor, Bogor.

Budiharsono, S. 2001. Teknik analisis pembangunan wilayah pesisir dan lautan. PT Pradinya Paramita, Jakarta.

BPS Kabupaten Karanganyar. 2013. Kabupaten Dalam Angka 2013. BPS Karanganyar, Karanganyar.
Djaelani, D., R. Widiati, dan K. A. Santosa. 2009. Pemberdayaan masyarakat melalui proyek gaduhan sapi potong di Kecamatan Oba Tengah dan Oba Utara, Tidore Kepulauan, Maluku Utara. Buletin Peternakan 33: 40-48.

Elly, F. M., B. M. Sinaga, S. U. Kuntjoro, dan N. Kusnadi. 2008. Pengembangan usaha ternak sapi rakyat melalui integrasi sapi tanaman di sulawesi utara. Jurnal Litbang Pertanian 27: 6368.

Emawati, S., R. Widiati, dan I. G. S. Budisatria. 2008. Analisis investasi usahatani pembibitan sapi potong di Kabupaten Sleman. Buletin Peternakan 32: 224-234.

Gray, C. dan P. Simanjuntak. 1993. Pengantar Evaluasi Proyek. PT. Gramedia, Pustaka Utama, Jakarta.

Gittinger, J. P. 1986. Analisa Ekonomi Proyek-Proyek Pertanian. Universitas Indonesia Press, Jakarta.

Gujarati, N. D. 2003. Basic Econometrics. $4^{\text {th }}$ edn. McGraw-Hill, New York.

Haming, M. dan S. Basalamah. 2003. Studi Kelayakan Investasi Proyek dan Bisnis. PPM, Jakarta.

Hartatik, T., D. A. Mahardika, T. S. M. Widi, dan E. Baliarti. 2009. Karakteristik dan kinerja induk sapi silangan LimousinMadura dan Madura di Kabupaten Sumenep dan Pamekasan. Buletin Peternakan 33: 143-147.

Husnan, S. dan M. Sarwono. 1994. Studi Kelayakan Proyek. Edisi Keempat. UPP, Yogyakarta.

Ibrahim, Y. H. M. 2003. Studi Kelayakan Bisnis, Edisi Revisi, Penerbit PT. Rineka Cipata, Jakarta.

Jumingan. 2009. Studi Kelayakan Bisnis: Teori dan pembuatan proposal kelayakan. PT. Bumi Akasara. Jakarta.

Kadariah, L. Karlina, dan C. Gray. 1999. Pengantar Evaluasi Proyek. Jilid 1. Fakultas Ekonomi, Universitas Indonesia, Jakarta.

Kasmir dan Jakfar. 2007. Studi Kelayakan Bisnis. Edisi Kedua. Prenada Media Group, Jakarta.

Luanmase, C. M., S. Nurtini, dan F. T. Haryadi. 2011. Analisis motivasi beternak sapi potong bagi peternak lokal dan transmigran serta pengaruhnya terhadap pendapatan di Kecamatan Kairatu, Kabupaten Seram 
Bagian Barat. Buletin Peternakan 35: 113-123.

Mukson, S. Marzuki, P. I. Sari, dan H. Setiyawan. 2008. Faktor-Faktor yang Mempengaruhi Potensi Pengembangan Ternak Sapi Potong Rakyat di Kecamatan Kaliori Kabupaten Rembang. Jawa Tengah. J. Indon. Trop. Anim. Agric. 33: 305-312.

Ngadiyono, N. 2007. Beternak Sapi. Citra Aji Pratama, Yogyakarta.

Ngadiyono, N. 2012. Beternak Sapi Potong Ramah Lingkungan. PT. Citra Aji Parama, Yogyakarta.

Pudjosumarto, M. 1991. Evaluasi Proyek. Liberty, Yogyakarta.

Roessali, W., B. T. Eddy, dan A. Muthardo. 2005. Upaya pengembangan usaha sapi potong melalui entitas agribisnis "Corporate Farming" di Kabupaten Grobongan. J. Anim. Agric. SocioEconomics 1: 25-30.

Saleh, E., Yunilas, dan Y. H. Sofyan. 2006. Analisis pendapatan peternak sapi potong di Kecamatan Hamparan Perak Kabupaten Deli Serdang. Jurnal Agribisnis Peternakan 2: 36-42.

Setiadi, A., S. I. Santoso, L. K. Nuswantara and Sunarso. 2012. Some factors influencing the income of Kaligesing goat farmers in Borobudur Subdistrict, Magelang Regency, Central Java, Indonesia. J. Indonesian Trop. Anim. Agric. 37: 308-313.
Sitindaon, S. H. dan Y. Zurriyati. 2012. Persepsi peternak rakyat terhadap sistem reproduksi dan kesehatan sapi di Kecamatan Bangkinang Seberang Kabupaten Kampar Provinsi Riau. Prosiding Seminar Nasional Teknologi Peternakan. Mataram 11 Desember 2012. HIm 25-37.

Soekartawi, 2006. Agribisnis Teori dan Aplikasi. Rajawali Press, Jakarta.

Susilowati, S. H., Sumaryanto, R. Nurmanaf, S. Friyatno, Rita N. S., H. Taringan, C. Muslim, dan N. K. Agustin. 2008. Arah Perubahan Penguasaan Lahan dan Tenaga Kerja Pertanian. Pusat Analisis Ekonomi dan Kebijakan Pertanian, Departemen Pertanian, Bogor.

Tarigan, R. 2007. Ekonomi Regional, Teori dan Aplikasi, PT. Bumi Aksara, Cetakan keempat, Jakarta.

Umar, H. 2009. Riset Pemasaran dan Perilaku Konsumen. Penerbit PT. Gramedia, Jakarta.

Yusdja, Y. dan N. Ilham. 2006. Arah kebijakan pembangunan peternakan rakyat. Pusat Analisis Sosial Ekonomi dan Kebijakan Pertanian. Analisis Kebijakan Pertanian 4: 18-38. 